\title{
Wanita Karir dan Perannya sebagai Ibu dalam Perspektif Hukum Islam
}

\author{
May Lyndha Marlina Lestari \\ IAI Agus Salim Lampung, Indonesia \\ E-mail: maylyndha39@gmail.com
}

\begin{abstract}
Article Info
Article History

Received: 2021-12-27

Revised: 2022-02-02

Published: 2022-02-18

Keywords:

Career woman

Perspective;

Islamic law.

Abstract

This study describes the study of career women and their role as mothers in the perspective of Islamic law. The method used in this study uses a library research method or approach, that library research can be interpreted as a series of activities related to the methods of collecting library data, reading and taking notes and processing research materials. The results of this study indicate that Islam does not prohibit women from leaving the house, contributing to society and Islam. Islam provides an opportunity for all of that. It is okay for a Muslim woman to have a career as long as she does not go out of the corridor of Islamic Sharia, a Muslim woman can work to help her husband, as long as she does not show off her genitals or cause arrogance, she can leave the house for an affair that is justified by the Shari'a, and does not sacrifice her honor and chastity. Things that career women can do in following the Shari'a are fulfilling Islamic social procedures and getting parental permission (if not married) or husband, and maintaining their views (ghadhdh al-bashar) for reasons that do not conflict with Islamic Shari'a.
\end{abstract}

\begin{tabular}{l}
\hline Artikel Info \\
\hline Sejarah Artikel \\
Diterima: $2021-12-27$ \\
Direvisi: 2022-02-02 \\
Dipublikasi: 2022-02-18
\end{tabular}

Kata kunci:

Wanita karir;

Perspektif;

Hukum Islam.

\begin{abstract}
Abstrak
Penelitian ini menjelaskan tentang kajian terhadap wanita karir dan perannya sebagai ibu dalam perspektif hukum islam. Metode yang digunakan dalam kajian ini menggunakan metode atau pendekatan kepustakaan (library research), bahwa studi pustaka atau kepustakaan dapat diartikan sebagai serangkaian kegiatan yang berkenaan dengan metode pengumpulan data pustaka, membaca dan mencatat serta mengolah bahan penelitian. Hasil penelitian ini menunjukkan bahwa Islam tidak melarang wanita keluar rumah, memberikan sumbangsihnya untuk masyarakat dan Islam. Islam memberikan kesempatan untuk semua itu. Berkarir bagi muslimah bolehboleh saja asalkan tidak keluar dari koridor Syariat Islam, wanita muslimah boleh bekerja membantu suaminya, asal tidak memamerkan aurat atau menimbulkan kesombongan, ia boleh keluar rumah untuk suatu urusan yang dibenarkan syariat, tidak mengorbankan kehormatan dan kesucian dirinya. Hal-hal yang dapat dilakukan wanita karir dalam mengikuti syariat yakni memenuhi tata cara pergaulan yang Islami dan mendapat izin orang tua (kalau belum menikah) atau suami, serta menjaga pandangannya (ghadhdh al-bashar) dengan alasan yang tidak bertentangan dengan syariat islam.
\end{abstract}

\section{PENDAHULUAN}

Di era yang semakin sulit dan kebutuhan hidup yang semakin tinggi memaksa para wanita untuk bekerja dan meninggalkan rumah demi membantu suami dalam memenuhi kebutuhan hidup dirinya dan keluarga. Seiring perkembangan zaman, saat ini masyarakat menilai bahwa pekerjaan wanita tidak hanya membantu suaminya mengurus rumah tangga saja akan tetapi mereka bisa menuntut ilmu setinggitingginya dan bekerja untuk mengaktualisasi ketrampilan dan pendidikannya (Arifudin, 2021). Islam sendiri sebagai agama yang adil telah menetapkan hak yang hilang dari wanita sebelum kedatangan Islam dan setelahnya, Dewasa ini peluang dalam dunia pendidikan bagi perempuan semakin besar, hampir semua jenjang dan jenis pendidikan bisa dimasuki perempuan, hampir tidak lagi ditemukan pendidikan khusus bagi laki-laki kecuali pendidikan dipesantren. Semua jurusan dan program studi, yang disediakan mulai dari humaniora sampai tekhnik mesin bisa dimasuki setiap orang tanpa membedakan jenis kelamin, secara tidak sengaja kebebasan ini ternyata memberi peluang kepada perempuan untuk bisa bersaing dalam memperoleh lapangan pekerjaan. Hal ini karena pendidikan yang dianggap sebagai label untuk memperoleh pekerjaan, telah membuat sejarah baru dalam kehidupan modern. Orang dianggap cakap, mampu, dan layak diterima dalam suatu 
pekerjaan karena jenjang pendidikannya yang semakin tinggi (Ulfah, 2022).

Disebabkan keberhasilan dalam proses pendidikan, atau kemampuan akademik yang diukur oleh pencapaian Indeks Prestasi Kumulatif (IPK) dijadikan pula sebagai ukuran untuk pertimbangan dalam menerima calon pekerja. Ditambah lagi, keberhasilan dalam proses pendidikan, atau kemampuan akademik yang dilambangkan dengan adanya Indeks Prestasi Kumulatif (IPK) justru dijadikan pula sebagai ukuran untuk pertimbangan dalam menerima calon pekerja (Arifudin, 2018). Kondisi ini telah menggeser persaingan untuk mendapatkan pekerjaan menjadi persaingan untuk memperoleh tempat dalam dunia pendidikan, merebut peluang dalam dunia pendidikan jauh lebih objektif, ilmiah, serta tidak diskriminatif terhadap gender. Seiring dengan berubahnya cara pandang masyarakat terhadap peran dan posisi kaum wanita di tengah-tengah masyarakat, maka kini sebagaimana kaum pria banyak kaum wanita yang berkarir, baik di kantor pemerintah maupun swasta bahkan ada yang berkarir di bidang kemiliteran dan kepolisian, sebagaimana pria (Labetubun, 2021), dalam kehidupan modern banyak wanita dapat bekerja dan berkarir dimana saja selagi ada kesempatan. Ada yang berkarir dalam hukum dan jaksa, ada yang terjun di bidang ekonomi, seperti menjadi pengusaha, pedagang, kontraktor dan sebagainya, ada pula yang bergerak di bidang sosial budaya dan pendidikan, seperti menjadi dokter, arsitek, artis, penyanyi, sutradara, guru dan lain-lain, bahkan ada pula yang terjun dalam bidang politik, misalnya menjadi presiden, anggota DPR, MPR, DPA, Menteri dan lain-lain.

Dalam ajaran Islam memberikan penghargaan akan peranan wanita dalam masyarakat, seperti halnya "Wanita adalah tiang negara", "Surga di bawah telapak kaki ibu", "Wanita membangun bangsa, pria membangun negara" dan lain sebagainya, bahkan pada dekade ini tahun 90 -an dikatakan sebagai era kepemimpinan wanita. Keterlibatan dan peranan wanita dalam membangun masyarakat dan negara adalah penting berdasarkan kepada tugas dan tanggung jawab pada berbagai pembangunan negara yang dapat disejajarkan dengan kaum pria, sumber daya manusia yang berkualitas bukan hanya dari kaum pria tetapi juga wanita (Arifudin, 2020). Secara umum Islam tidak menghalangi kaum wanita untuk melakukan pekerjaan yang baik di luar rumah sekiranya ia merupakan keperluan diri dan keluarga atau untuk masyarakat dan negara. Atas dasar keperluan inilah wanitawanita pada zaman nabi Muhammad SAW bekerja sama membantu keluarga mereka seperti mengembala, bertani, berdagang dan sebagainya. Sebagai contoh Asma' binti Abu Bakar yang bekerja sebagai petani untuk membantu suaminya dalam mengangkat hasil pertanian dari ladang ke pasar yang jauhnya kira-kira 1,4 km.

Islam menganjurkan umatnya untuk menikmati dunia dan apa yang ada didalamnya, dengan syarat tetap berada dalam batas-batas yang telah ditentukan oleh Allah. Islam bahkan mengharuskan manusia untuk memanfaatkan semua yang baik yang disediakan oleh Allah karena semua itu penopang kesejahteraan (Mahmud, 2004). Di era globalisasi tentu diperlukan perumusan ulang peran wanita yang relevan dengan tantangan zamannya, mengingat perubahan zaman sedemikian cepatnya, dan perubahan tersebut menawarkan nilai-nilai baru yang mungkin tidak serasi sebagai penapisan sehingga tidak terjadi kekosongan nilai (anomi), peran wanita sebagai pelaku utama sosialisasi primer tidak dapat disangkal, dalam konteks itu wanita dituntut memiliki peran yang multi dimensi. Berpendidikan tinggi, berwawasan luas, pintar, menjunjung tinggi nilai-nilai etika masyarakat serta mampu mendorong anak-anak berbudi luhur, jenius dan berdaya juang tinggi. Semua itu merupakan landasan bagi genarasi penerus yang akan menentukan nasib bangsa ini. Karenanya wanita harus memiliki keperibadian kuat dan teguh, berakhlak mulia serta peduli dalam segala hal (Al-Hasymi, 2004). Menjadi wanita karir memang tidak dilarang akan tetapi ia tidak boleh melalaikan tugasnya sebagai seorang istri atau ibu untuk mengurus rumah tangga atau keluarganya serta mendidik anakanaknya. Wanita selayaknya memberikan perhatian dan waktu yang cukup pada keluarganya meskipun ia bekerja diluar rumah, oleh karenanya dalam melihat wanita karir dan perannya sebagai ibu dalam perspektif hukum Islam perlu dilakukan penelitian secara komprehensif berdasar pada kajian-kajian pustaka yang relevan.

\section{METODE PENELITIAN}

Sesuai dengan karakteristik masalah yang diangkat dalam penelitan ini maka menggunakan Metode Riset kualitatif, yaitu menekankan analisanya pada data deskriptif berupa kata-kata tertulis yang diamati, pendekatan kualitatif penulis gunakan untuk menganalisis kajian terhadap wanita karir dan perannya sebagai ibu 
dalam perspektif hukum Islam. Maka dengan sendirinya penganalisaan data ini lebih difokuskan pada Penelitian Kepustakaan (Library Research), yakni dengan membaca, menelaah dan mengkaji buku-buku dan sumber tulisan yang erat kaitannya dengan masalah yang dibahas (Na'im, 2021). Metode yang digunakan dalam kajian ini menggunakan metode atau pendekatan kepustakaan (library research), menurut Zed dalam (Rahayu, 2020) bahwa studi pustaka atau kepustakaan dapat diartikan sebagai serangkaian kegiatan yang berkenaan dengan metode pengumpulan data pustaka, membaca dan mencatat serta mengolah bahan penelitian.

Jenis penelitian ini adalah penelitian kualitatif, Menurut Ibnu dalam (Arifudin, 2019) penelitian kualitatif adalah suatu penelitian yang datanya dinyatakan dalam bentuk verbal dan dianalisis tanpa menggunakan teknik statistik, berdasarkan beberapa definisi penelitian kualitatif di atas dapat disimpulkan bahwa penelitian kualitatif adalah suatu penelitian yang datanya dinyatakan dalam bentuk verbal, tidak menggunakan angka dan analisisnya tanpa menggunakan teknik statistik.

1. Objek Penelitian

Dalam penelitian ini objek penelitian terdiri dari 2 (dua), yaitu objek formal dan objek material (Tanjung, 2022). Objek formal dalam penelitian ini berupa data yaitu data yang berhubungan dengan tinjauan kritis kajian terhadap wanita karir dan perannya sebagai ibu dalam perspektif hukum islam, sedangkan objek materialnya berupa sumber data, dalam hal ini adalah tinjauan kritis kajian terhadap wanita karir dan perannya sebagai ibu dalam perspektif hukum islam.

2. Waktu Penelitian

Penelitian ini dilaksanakan pada bulan November sampai dengan Desember tahun 2021.

3. Teknik Pengumpulan Data

Pengumpulan data yang dilakukan dengan menggunakan teknik dokumentasi yaitu mengadakan survey bahan kepustakaan untuk mengumpulkan bahan-bahan dan studi literatur yakni mempelajari bahan-bahan yang berkaitan dengan objek penelitian. Teknik pengumpulan data menurut (Bahri, 2021) mengemukakan bahwa merupakan langkah yang paling strategis dalam penelitian karena tujuan untama dari penelitian adalah mendapatkan data, terdapat beberapa cara atau teknik dalam mengumpulkan data, diantaraljnya adalah observasi dan dokumentasi.
Sumber data yang digunakan dalam penelitian ini mencakup data primer dan sekunder. Menurut (Hanafiah, 2021) bahwa data primer adalah data yang dikumpulkan langsung dari individu-individu yang diselidiki atau data tangan pertama. Sedangkan data sekunder adalah data yang ada dalam pustaka-pustaka. Data primer dalam penelitian ini adalah bukubuku terkait tinjauan kritis kajian terhadap wanita karir dan perannya sebagai ibu dalam perspektif hukum Islam, dan data sekunder didapatkan dari jurnal-jurnal baik nasional maupun internasional.

4. Alat Pengumpulan Data

Dalam penelitian ini penulis akan menggunakan metode dokumentasi sebagai alat untuk pengumpul data karena penelitian ini adalah penelitian kepustakaan, dengan kata lain menurut (Shavab, 2021) bahwa teknik ini digunakan untuk menghimpun data-data dari sumber primer maupun sekunder.

\section{Teknik Analisis Data}

Analisis data tidak saja dilakukan setelah data terkumpul, tetapi sejak tahap pengumpulan data proses analisis telah dilakukan. Penulis menggunakan strategi analisis "kualitatif", strategi ini dimaksudkan bahwa analisis bertolak dari data-data dan bermuara pada kesimpulan-kesimpulan umum, berdasarkan pada strategi analisis data ini, dalam rangka membentuk kesimpulan-kesimpulan umum analisis dapat dilakukan menggunakan kerangka pikir "induktif". Menurut (Sugiyono, 2015) bahwa metode pembahasan menggunakan metode deskriptif-analisis, yaitu menjelaskan serta mengelaborasi ide-ide utama yang berkenaan dengan topik yang dibahas, kemudian menyajikannya secara kritis melalui sumber-sumber pustaka primer maupun skunder yang berkaitan dengan tema.

6. Prosedur Penelitian

Data pada penelitian ini dicatat, dipilih dan kemudian diklasifikasikan sesuai dengan kategori yang ada, pendekatan yang digunakan adalah pendekatan deskriptif analitis. Menurut (Siregar, 2021) bahwa deskriptif analitis (descriptive of analyze research), yaitu pencarian berupa fakta, hasil dari ide pemikiran seseorang melalui cara mencari, menganalisis, membuat interpretasi serta melakukan generalisasi terhadap hasil penelitian yang dilakukan. Prosedur penelitian ini (Silaen, 2021) adalah untuk menghasilkan data deskriptif yang berupa data tertulis setelah melakukan analisis pemikiran (content 
analyze) dari suatu teks. Setelah penulis mengumpulkan bahan-bahan yang berhubungan dengan masalah yang akan di bahas dalam penelitian ini, kemudian penulis menganalisis dan menarasikan untuk diambil kesimpulan.

\section{HASIL DAN PEMBAHASAN}

Dalam pembahasan ini akan dibahas tentang Wanita Karir, Berbagai Pendapat Hukum Wanita Karir, serta Problematika Wanita Karir dan Pemecahannya.

1. Wanita Karir

Dalam ajaran Islam tidak menganjurkan wanita bekerja mencari nafkah di luar rumah, tapi juga tidak melarang, bila keadaan memaksa, dalam artian tak ada lagi orang yang bisa diharap menanggung biaya hidup, sejarah memperlihatkan profil Khodijah, wanita cantik, pintar, kaya dan hanif, berhasil dalam karya, perdagangan yang dilakukannya untuk mendanai kebutuhan dan kepentingan Islam dan muslimin sehingga meski bertugas ganda tapi tidak mengabaikan peranan utamanya. Demikian juga Asma' putri Abu Bakar yang mengerahkan segenap kemampuannya untuk membantu kelancaran dakwah sang suami, Zubair yang taqwanya sebagai aset ukhrowi yang tak dapat ditukar dengan benda apapun dari perhiasan dunia. Asma' sebagai istri, mengurus kudanya pekerjaan yang menurut kriteria banyak wanita modern sebagai pekerjaan kasar, Asma' melakukan dengan ikhlas hati tanpa rendah diri bantuan yang diberikan kepada suaminya, berarti bantuan kepada dakwah Islam. Wanita karier yang disibukan dengan bekerja diluar rumah sering di istilahkan dengan wanita karier, istilah "karier" dari segi bahasa adalah sebuah istilah yang tidak hanya mencakup keikutsertaan pada lapangan kerja tetapi lebih merupakan kesukaan atau ketertarikan pada pekerjaan upahan dalam waktu lama, atau paling tidak mendambakan kemajuan dan peningkatan dalam waktu tertentu (Jusmaliani, 2008).

Secara lebih jelas wanita karier adalah wanita yang menekuni dan mencintai sesuatu atau beberapa pekerjaan secara penuh dalam waktu yang relatif lama, untuk mencapai suatu kemajuan dalam hidup, pekerjaan atau jabatan, untuk berkarier berarti harus menekuni profesi tertentu yang membutuhkan kemampuan dan keahlian, pekerjaan yang paling baik bagi wanita adalah menjadi perawat. Sekolah-sekolah perawat baik yang ditingkat dasar maupun ditingkat tinggi, adalah tempat terbaik untuk melatih dan mengajar wanita. Rumah sakit adalah tempat yang baik pula bagi wanita, untuk bekerja sebagai perawat atau dokter, pekerjaan semacam itu cocok bagi sifat-sifat kewanitaan (Ibrahim, 1988).

Wanita Karir berarti wanita yang memiliki pekerjaan dan mandiri finansial baik kerja pada orang lain atau punya usaha sendiri. Ia identik dengan wanita pintar dan perempuan modern. Ketiga label ini bisa positif tapi juga negatif tergantung bagaimana dia bisa membawa diri secara agama dan sosial, dengan demikian dapat dirumuskan bahwa "wanita karir" adalah wanita yang menekuni sesuatu atau beberapa pekerjaan yang dilandasi oleh keahlian tertentu yang dimilikinya untuk mencapai suatu kemajuan dalam hidup, pekerjaan, atau jabatan. Wanita diciptakan oleh Allah SWT sebagai makhluk yang mempunyai keistimewaan dan kepentingan yang tersendiri, menurut sejarah awal kehidupan semua manusia berasal dari keturunan yang sama, yaitu Nabi Adam, kemudian diciptakan wanita pertama, yaitu Hawa sebagai pasangan Nabi Adam. Bermula dengan penyatuan kedua-duanya lahirlah generasi manusia dari dahulu hingga sekarang, hingga saat ini banyak wanita sukses di dunia dan menjadi orang berpengaruh dalam bidangnya masing-masing.

\section{Berbagai Pendapat Hukum Wanita Karir}

Ada berbagai pendapat mengenai wanita karier ini yang semuanya berdasarkan alasan tersendiri, diantaranya:

a) Melarang Wanita Menjadi Wanita Karier

Menurut ulama yang berpendapat seperti ini, pada dasarnya hukum karir wanita di luar rumah adalah terlarang, karena dengan bekerja diluar rumah maka akan ada banyak kewajiban dia yang harus ditinggalkan. Misalnya melayani keperluan suami, mengurusi dan mendidik anak serta hal lainnya yang menjadi tugas dan kewajiban seorang istri dan ibu, padahal semua kewajiban ini sangat melelahkan yang membutuhkan perhatian khusus, semua kewajiban ini tidak mungkin terpenuhi kecuali kalau seorang wanita tersebut memberi perhatian khusus padanya. Larangan ini didasarkan bahwa suami diwajibkan untuk membimbing istrinya pada jalan kebaikan sedang istri diwajibkan mentaatinya, begitu pula dengan hal 
dunia laki-laki dan wanita, maka Islam menjadikan laki-laki diluar rumah untuk mencari nafkah bagi keluarganya, sebagaimana sabda Rasululloh SAW: "Dan hak para istri atas kalian (suami) agar kalian memberi mereka nafkah dan pakaian dengan cara yang ma"ruf." (HR. Muslim), disisi lainnya tempat wanita dijadikan di dalam rumah untuk mengurusi anak, mendidiknya, mempersiapkan keperluan suami serta urusan rumah tangga dan lainnya. Rasululloh SAW menggambarkan hal ini dalam sabdanya yang mulia: "Dan wanita adalah pemimpin dirumah suaminya dan dia akan dimintai pertanggung jawaban atas yang dipimpinnya." (HR. Bukhori)

b) Memperbolehkan Wanita Berkarier Di Luar Rumah, jika memang ada sesuatu yang sangat mendesak untuk berkarirnya wanita diluar rumah maka hal ini diperbolehkan, syari'at Islam tidak melarang wanita bekerja selama adab syar'i tetap dijaga tidak terjadi ikhtilath antara pria dan wanita sehingga secara minim tidak produktif. Perlu dikatahui bahwa busana muslimat awal satu langkah untuk membentuk pribadi yang luhur untuk kesempurnaan ibadah dan akhlak (Al-Jami, 1984), dalam agama Islam ada beberapa tata krama seorang wanita yang memiliki aktivitas di luar rumah, diantaranya:

1) Tidak keluar rumah kecuali seizin suaminya, hendaknya ia keluar dengan tidak bershias mencari jalan yang sepi dan tidak ditempat ramai, menjaga suaranya agar tidak mengundang nafsu laki-laki.

2) Menjaga kehormatan suaminya serta mendukung dan mendorong pekerjaan suaminya, tidak berniat menghianti suami dan hartanya.

3) Senantiasa memperbaiki dirinya dan mengatur rumah tangganya dengan baik, tidak melupakan kewajibannya sebagai hamba Allah dan sebagai seorang istri.

4) Senantiasa merasa cukup dengan pemberian suaminya dari rezki yang diberikan Allah SWT.

5) Hendaknya ia mendahulukan hak suami dibandingkan hak dirinya dan sahabatnya.

6) Tidak mengungkit-ungkit kesalahan suami.
7) Istri tidak membangga-banggakan kecantikannya dan melecehkan keburukan suaminya (Al-Gazali, 2001).

Selanjutnya Islam melihat hukum wanita karir adalah mubah, selama ia masih menjaga kodratnya sebagai wanita, sebagai ibu dan sebagai istri dan apa yang diperolehnya merupakan suatu ibadah sedekah terhadap rumah tangganya, hukum tersebut bisa berubah menjadi haram, bila para wanita melalaikan tugasnya dan bekerja tanpa izin suaminya, namun harus dipahami bahwa sebuah kebutuhan yang mendesak ini harus ditentukan dengan kadarnya yang sesuai sebagaimana sebuah kaidah fiqhiyah yang masyhur dan kebutuhan yang mendesak ini misalnya:

1) Rumah tangga memerlukan kebutuhan pokok yang mengharuskan wanita bekerja, Misalnya karena suaminya atau orang tuanya meninggal dunia atau keluarganya sudah tidak bisa memberi nafkah karena sakit atau lainnya, sedangkan negara tidak memberikan jaminan pada keluarga semacam mereka. Lihatlah kisah yang difirmankan Allah dalam Surat Al Qoshosh 23 dan 24 yang artinya: "Dan tatkala ia sampai di sumber air negeri Madyan ia menjumpai di sana sekumpulan orang yang sedang meminumkan (ternaknya), dan ia menjumpai di belakang orang banyak itu, dua orang wanita yang sedang menghambat (ternaknya).

2) Tenaga wanita tersebut dibutuhkan oleh masyarakat, dan perkerjaan tersebut bisa dilakukan oleh laki-laki, Hal yang menunjukkan hal ini adalah bahwa di zaman Rosulullah ada para wanita yang bertugas membantu kelahiran, semacam dukun bayi atau bidan pada saat ini, juga saat itu ada wanita yang mengkhitan anak-anak wanita dan yang dhohir bahwa perkerjaan ini mereka lakukan diluar rumah. Pada zaman ini bisa ditambahkan yaitu dokter wanita spesialis kandungan, perawat saat bersalin, tenaga pengajar yang khusus mengajar wanita dan yang sejenisnya, diantara pekerjaan wanita yang ada pada zaman Rosululloh adalah apa yang diriwayatkan oleh Anas bin Malik radhiyallahuanhu berkata: "Rasululloh shallallahu „alaihi wa sallam berperang bersama Ummu Sulaim dan beberapa wanita anshor, maka mereka memberi minum dan mengobati orang yang terluka (Huzaimah, 2010). 
3. Problematika Wanita Karir dan Pemecahannya

Islam tidak menganjurkan wanita bekerja mencari nafkah di luar rumah, tapi juga tidak melarang, bila keadaan memaksa, dalam artian tak ada lagi orang yang bisa diharap menanggung biaya hidup, masyarakat akan sejahtera apabila warganya berakhlak luhur, di mana terdapat kesadaran umum tentang pentingnya hukum Allah SWT, dan sebagai standar khususnya bila wanita sudah bisa dikendalikan maka akan terwujud keluhuran insani. Islam berkepentingan membentuk wanita sholihat, qonitat, abidat yang akan melahirkan putra-putri beriman, peranan penting yang dimainkan wanita hari ini besar sekali artinya dalam membentuk generasi mendatang. Wanita dihadapkan pada dua kekuatan yaitu satu kekuatan baik yang memberinya gambaran tentang kebaikan, sementara kekuatan lain menariknya untuk bergabung ke dalam pegerakan-pergerakan wanita agar berperan mencapai kemajuan, kejayaan dan cita-cita serta meraih beberapa prestasi dan prestise dan apa saja yang didambakannya. Wanita boleh saja keluar dan berkarier di luar rumah apabila ada keperluan bagi seorang wanita untuk bekerja keluar rumah maka harus memenuhi beberapa ketentuan syar'i agar kariernya tidak menjadi perkerjaan yang haram, Syarat-syarat itu adalah:

a) Memenuhi adab keluarnya wanita dari rumahnya baik dalam hal pakaian ataupun lainnya.

b) Mendapat izin dari suami atau walinya. Wajib hukumnya bagi seorang istri untuk mentaati suaminya dalam hal kebaikan dan haram baginya mendurhakai suami, termasuk keluar dari rumah tanpa izinnya.

c) Pekerjaan tersebut tidak ada kholwat dan ikhtilat (Campur baur) antara laki- laki dan wanita yang bukan mahram. Sebagaimana firman Allah dalam Al- Qur'an Surat AlAhzab ayat 53 yang berbunyi: Artinya "Dan apabila kalian meminta pada mereka sebuah keperluan, maka mintalah dari balik hijab"

d) Tidak menimbulkan fitnah, wanita yang berkarier di luar rumah tidak menimbulkan fitnah, hal ini dapat dilakukan dengn cara menutupi seluruh tubuhnya dihadapan laki-laki asing dan menjauhi semua hal yang berindikasi fitnah, baik di dalam berpakaian, berhias atau pun berwangiwangian (menggunakan parfum).

e) Tetap bisa mengerjakan kewajibannya sebagai ibu dan istri bagi keluarganya, karena itulah kewajibannya yang asasi.

f) Hendaknya pekerjaan tersebut sesuai dengan tabi'at dan kodratnya seperti dalam bidang pengajaran, kebidanan, menjahit dan lain-lain.

Semua fenomena di atas menjelaskan terang, betapa wanita Muslimah dapat bergerak dan melangkah memfungsikan potensi dan keterampilannya tanpa harus mengorbankan kehormatan dan kesucian dirinya, sebab akhlak adalah kunci diutusnya nabi, "Aku diutus ke dunia unluk menyempurnakun akhlak al-karimah". Akhlak itulah kunci keberhasilan eksistensi suatu masyarakat, bangsa dan amal, tanpa akhlak, bangsa dan masyarakat tak lebih dari hewan-hewan yang liar tiada kebaikan yang dapat diharapkan darinya, hampa tak bermakna.

\section{SIMPULAN DAN SARAN}

\section{A. Simpulan}

Berdasarkan pemaparan pada penelitian wanita karir dan perannya sebagai ibu dalam perspektif hukum Islam ini dapat disimpulkan bahwa Islam tidak melarang wanita keluar rumah, menikmati udara segar, memberikan sumbangsihnya untuk masyarakat dan Islam. Islam memberikan kesempatan untuk semua itu, wanita muslimah dipersilahkan mengekspresikan potensi dan keterampilan dirinya untuk kemaslahatan bersama. Ia diperkenankan berbuat, bergerak, namun harus sesuai dengan tuntutan Islam, wanita muslimah boleh bekerja membantu suaminya asal tidak memamerkan aurat atau menimbulkan kesombongan. Ia boleh keluar rumah untuk suatu urusan yang dibenarkan syariat, tidak mengorbankan kehormatan dan kesucian dirinya, wanita muslimah boleh menghayati hakekat suatu pekerjaan dan peran utamanya adalah ratu keluarga, petaka rumah tangga yang akan melahirkan manusia-manusia teladan, sebab dialah tiang negara, maju mundurnya negara tergantung pada wanitanya. Berkarier bagi muslimah boleh-boleh saja asalkan tidak keluar dari koridor Syariat Islam yakni memenuhi tata cara pergaulan yang Islami dan mendapat izin orang tua (kalau belum menikah) atau suami, serta menjaga pandangannya (ghadhdh al-bashar) dan 
dengan alasan yang tidak bertentangan dengan syariat islam.

\section{B. Saran}

Pembahasan terkait penelitian kajian terhadap wanita karir dan perannya sebagai ibu dalam perspektif hukum Islam dalam penelitian ini masih sangat terbatas dan membutuhkan banyak masukan, saran untuk penulis selanjutnya adalah mengkaji lebih dalam dan secara komprehensif terkait kajian terhadap wanita karir dan perannya sebagai ibu dalam perspektif hukum islam.

\section{DAFTAR RUJUKAN}

Al-Gazali. (2001). Rahasia Dibalik Tirai Pernikahan. Jakarta: Kalam Mulia.

Al-Hasymi. (2004). Jati diri wanita muslimah. Jakarta: Gema Insani.

Al-Jami. (1984). Muhammad, Pelita Rumah Tangga Islam (Wanita Karir). Bandung: Pustaka Setia.

Arifudin, 0. (2021). Manajemen Strategik Teori Dan Implementasi. Banyumas: Pena Persada.

Arifudin, O. (2020). Pengaruh Penjualan Personal Dan Lokasi Terhadap Volume Penjualan (Survey Pada Dealer Kamera Digital Panasonic Di Kota Bandung). Managament Insight: Jurnal Ilmiah Manajemen, 15(2), 232-241.

Arifudin, O. (2019). Pengaruh Kompensasi Terhadap Kinerja Karyawan Di PT. Global (PT.GM). Jurnal Ilmiah MEA (Manajemen, Ekonomi, \& Akuntansi), 3(2), 184-190.

Arifudin, O. (2018). Pengaruh Pelatihan Dan Motivasi Terhadap Produktivitas Kerja Tenaga Kependidikan STIT Rakeyan Santang Karawang. MEA (Manajemen, Ekonomi, \& Akuntansi), 2(3), 209-218.

Atha. (2000). Adabun Nabi. Beirut: Pustaka Azzam.

Bahri, A. S. (2021). Pengantar Penelitian Pendidikan (Sebuah Tinjauan Teori dan Praktis). Bandung: Widina Bhakti Persada.
Hanafiah, H. (2021). Pelatihan Software Mendeley Dalam Peningkatan Kualitas Artikel Ilmiah Bagi Mahasiswa. Jurnal Karya Abdi Masyarakat, 5(2), 213-220.

Ibrahim. (1988). Bimbingan Islam Untuk Kehidupan Suami Istri. Bandung: Anggota IKAPI.

Jusmaliani. (2008). Bisnis Berbasis Syariah, Cet I. Jakarta: Bumi Aksara.

Labetubun, M. A. H. (2021). Sistem Ekonomi Indonesia. Bandung : Widina Bhakti Persada.

Mahmud. (2004). Akhlak Mulia. Jakarta: Gema Insani.

Na'im, Z. (2021). Manajemen Pendidikan Islam. Bandung: Widina Bhakti Persada.

Rahayu, Y. N. (2020). Program Linier (Teori Dan Aplikasi). Bandung : Widina Bhakti Persada.

Shavab, F. A. (2021). Dasar Manajemen \& Kewirausahaan (Sebuah Tinjauan Teori Dan Praktis). Bandung : Widina Bhakti Persada.

Silaen, N. R. (2021). Kinerja Karyawan. Bandung: Widina Bhakti Persada.

Siregar, R. T. (2021). Komunikasi Organisasi. Bandung : Widina Bhakti Persada.

Sofyan, Y. (2020). Peranan Konseling Dosen Wali Dalam Meningkatkan Motivasi Belajar Mahasiswa Di Perguruan Tinggi Swasta Wilayah LLDIKTI IV. Jurnal Bimbingan Dan Konseling Islam, 10(2), 237-242.

Sugiharto. (2008). The Inner Power of Muslimah. Jakarta: PT Mizan Publika.

Sugiyono. (2015). Metode Penelitian Pendidikan (Pendekatan Kuantitatif,. Kualitatif dan $R \& D)$. Bandung : CV. Alfabeta.

Tanjung, R. (2022). Manajemen Mutu Dalam Penyelenggaraan Pendidikan. Jurnal Pendidikan Glasser, 6(1), 29-36.

Ulfah, U. (2022). Kepemimpinan Pendidikan di Era Disrupsi. JIIP-Jurnal Ilmiah Ilmu Pendidikan, 5(1), 153-161. 